als on 392 patients with verified diagnoses of lambliasis and opisthorchiasis. Thus, it testifies about its antiparasitic activity. The Karaganda pharmaceutical complex was constructed and put into operation on the basis of holding «Phytochemistry». The complex has capacity of 2 millions ampoules, 150 millions tablets, capsules and 2 millions soft dosage forms of original competitive phytopreparations.

\title{
A NEW SPIRO-SESQUITERPENOIDIC CHROMANDIONE FROM GUM AMMONIACUM WITH ACETYLCHOLINESTERASE INHIBITORY ACTIVITY
}

\author{
(C) Adhami H. R. ${ }^{1}$, Kaehlig H. ${ }^{2}$, Zehl M. ${ }^{1}$, Krenn L. ${ }^{1}$
}

${ }^{1}$ Department of Pharmacognosy, University of Vienna, Austria

${ }^{2}$ Institute of Organic Chemistry, University of Vienna, Austria
Attempts to restore cholinergic function have been considered as a rational target to improve the symptoms of Alzheimer's disease. One therapeutic option is the use of AChE inhibitors which block this key enzyme in the breakdown of acetylcholine (1). During the last decade the use of herbal medicinal preprations in dementia therapy has been studied based on traditional medicine (2). Gum ammoniacum is a gum-resin from Dorema ammoniacum D. Don which has been used in Unani and Iranian traditional medicine for several indications. A previous study showed AChE inhibitory activity for a dichloromethane extract of this resin (3). The aim of this study was the isolation and characterization of active compounds from gum ammoniacum. Extraction of the resin was performed by sonification with dichloromethane. The extract was investigated by a respective colorimetric microplate assay and the active zones were identified via TLC bioautography. Then the active compounds were isolated using several chromatographic techniques such as vacuum liquid chromatography, column chromatography and counter current chromatography. The structures of the active components were characterized by different methods such as one and two-dimension$\mathrm{al}^{1} \mathrm{H}$ and ${ }^{13} \mathrm{C}$ NMR spectroscopy (COSY, TOCSY, HSQC, HMBC, NOESY) and mass spectrometry. Two spirosesquiterpenoidic chromadiones were characterized as active components and one of them is a new compound. Their $\mathrm{IC}_{50}$ values for AChE inhibitory activity were determined by microplate assay as 77 and $100 \mu \mathrm{g} / \mathrm{ml}$. The extract was analyzed by HPLC to determine the concentration of active compounds in the extract.

References: (1) Howes MJ, Houghton PJ. 2003. Pharmacol Biochem Behav. 75: 513-527. (2) Andrade C, Sudha S, Venkataraman BV. 2000. J ECT. 16: 144-156. (3) Adhami HR, Farsam H, Krenn L. 2011. Phytother Res. 25: 1148-1152.

\section{EFFECT OF MARJORAM POWDER (ORIGANUMMAJORANA L.) AS ANTIBIOTIC GROWTH PROMOTER SUBSTITUTIONS ON PERFORMANCE AND IMMUNITY OF BROILER CHICKS}

\section{(C) Aghdam Shahryar Habib ${ }^{1}$, Akhavan Movahed Iman ${ }^{1}$, Toghyani Majid $^{2}$}

1Department of Animal Science, Shabestar Branch, Islamic Azad University, Shabestar, Iran
${ }^{2}$ Department of Animal Science, Khorasgan Branch, Islamic Azad University, Isfahan, Iran

This experiment was conducted to evaluate the effect of marjoram powder (Origanummajorana L.) as an antibiotic growth promoter substitution on performance and immune responses in broiler chicks. Three hundred day-old broiler chicks were divided randomly into four treatment groups included: control (Basal diet), antibiotic (Flavophospholipol) and marjoram powder at levels of 2 and $4 \mathrm{~g} / \mathrm{kg}$ in basal diet. Body weight, feed intake and feed conversion were recorded at 14, 28 and $46 \mathrm{~d}$. Antibody titer against Newcastle and Avian Influenza (H9 N2) viruses at $26 \mathrm{~d}$ (14 d post immunization), SRBC at $32 \mathrm{~d}$
(6 d post immunization) and heterophil to lymphocyte ratio at $42 \mathrm{~d}$ were measured. Results showed that the birds fed the 2 or $4 \mathrm{~g} / \mathrm{kg}$ marjoram powder had higher final body weight than other treatments $(P<0.05)$. Feed consumption in antibiotic group was significantly decreased. Feed conversion ratio was not affected by dietary treatments. Antibody titer against Newcastle and Influenza viruses were elevated in broiler chicks fed $4 \mathrm{~g} / \mathrm{kg}$ marjoram pow$\operatorname{der}(\mathrm{P}<0.05)$. Antibody titer against SRBC, albumin to globulin ratio and heterophil to lymphocyte ratio were not affected by dietary treatments. These results suggest that 